tion abandoned prematurely? In Vorren, T, O. et al. (ed.) Arctic geology and petroleum potential. Amsterdam: Elsevier for Norwegian Petroleum Society.

Dam, G. in review: Wave- and storm-dominated lacustrine deltas, Kap Stewart Formation (Rhaetian-Sinemurian), Jameson Land, East Greenland. Sediment. Geol.

Dam, G. \& Christiansen, G. 1990: Organic geochemistry and source potential of the lacustrine shales of the Upper Triassic - Lower Jurassic Kap Stewart Formation, East Greenland. Marine Petrol. Geol. 7, 428-443.

Kalsbeek, F. 1990: Disko Bugt Project, central West Greenland. Rapp. Grønlands geol. Unders. 148, 21-24.

Larsen, H. C. 1990: The East Greenland Shelf. In Grantz, A., Johnson, [G.] L. \& Sweeney, J. F. (ed.) The geology of North America, L. The Arctic Ocean region, 185-210. Boulder, Colorado: Geological Society of America.

Larsen, H. C. \& Pulvertaft, T. C. R. 1990: Regional marine seismic reconnaissance. Rapp. Grønlands geol. Unders. 148, 32-34.

Larsen, P.-H. \& Olsen, H. 1991: The Devonian basin project, North-East Greenland - a summary. Rapp. Grønlands geol. Unders. 152 (this volume).
Stemmerik, L., Pulvertaft, T. C. R. \& Larsen, H. C. 1990a: Current activities in the field of hydrocarbon geology. Rapp. Grønlands geol. Unders. 148, 24-29.

Stemmerik, L., Christiansen, F. G. \& Piasecki, S. 1990b: Oliepotentialet i Østgrønland nord for $72^{\circ} \mathrm{N}$. Unpubl. GGU rep. submitted to Mineral Resources Administration for Greenland, 31 pp. +27 appendices.

Stemmerik, L., Christiansen, F. G. \& Piasecki, S. 1991: Evaluation of the hydrocarbon potential onshore North-East Greenland $\left(72^{\circ}-75^{\circ} \mathrm{N}\right)$. Rapp. Grønlands geol. Unders. 152 (this volume).

Stemmerik, L., Christiansen, F. G., Piasecki, S., Jordt, B., Marcussen, C. \& Nøhr-Hansen, H. in press: Depositional history and petroleum geology of the Carboniferous to Cretaceous sediments in the northern part of East Greenland. In Vorren, T. O, et al. (ed.) Arctic geology and petroleum potential. Amsterdam: Elsevier for Norwegian Petroleum Society.

T. C. R. P., Geological Survey of Greenland, Copenhagen.

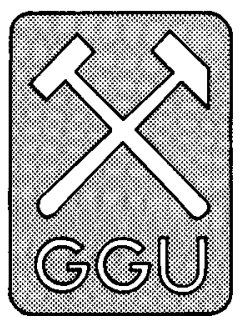

\section{Evaluation of the hydrocarbon potential onshore North-East Greenland $\left(72^{\circ}-75^{\circ} \mathrm{N}\right)$}

\author{
Lars Stemmerik, Flemming G. Christiansen \\ and Stefan Piasecki
}

In 1986 the Geological Survey of Greenland (GGU) initiated a major field and laboratory programme in the onshore areas of North-East Greenland in order to evaluate the petroleum potential and provide basic petroleum geological information for future exploration in the region (Fig. 1).

The main petroleum geological interest in North-East Greenland is focussed on the 5-6 km thick Carboniferous-Cretaceous succession (Fig. 2). These deposits have previously only been superficially studied with the exception of the Jurassic - Lower Cretaceous succession (Surlyk, 1977, 1978).

GGU's programme included detailed dating of the Carboniferous and Cretaceous sediments, identification and quantification of potential source rocks, mapping of the regional maturity pattern, and sedimentological studies of the Carboniferous and Permian sediments. The main results, summarised below, are published in an overview paper by Stemmerik et al. (in press) and in a number of more detailed contributions (Christiansen et al., 1990a, in press; Piasecki et al., 1990; Piasecki \& Stemmerik, in press; Rasmussen et al., 1990; Stemmerik et al., 1991a, b). Furthermore, a number of internal reports dealing with these topics are available from GGU (e.g. Christiansen, 1990; Christiansen \& Boserup, 1990; Christiansen et al., 1990b, c; Vigran, 1990a, b).

\section{Potential source rocks}

Potential source rocks (i.e. rocks that could generate hydrocarbons if suitably mature) occur at three stratigraphic levels in the area investigated (Fig. 2). These sediments are:

(1) Westphalian (Upper Carboniferous) lacustrine shales; 


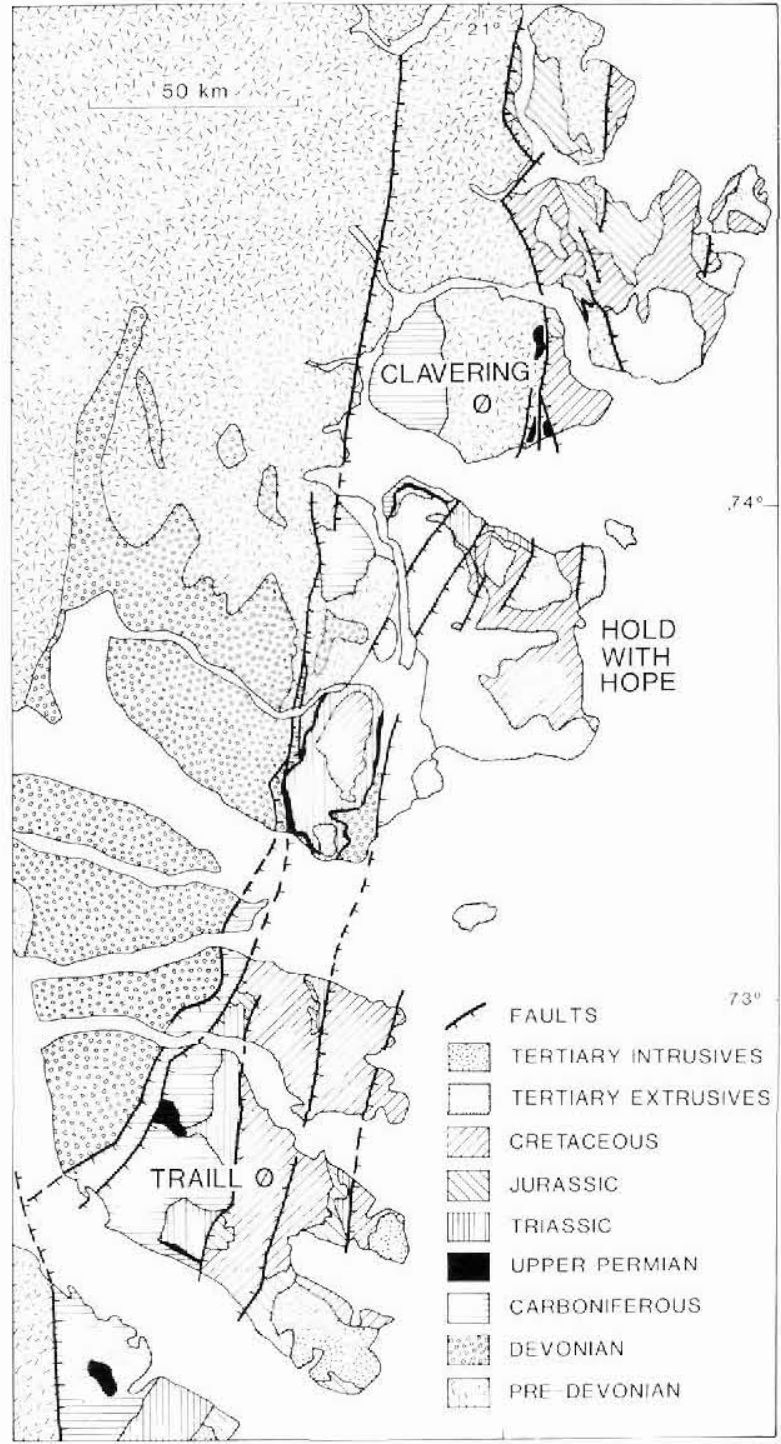

Fig. 1. Simplified geological map of North-East Greenland between $72^{\circ}$ and $75^{\circ} \mathrm{N}$.

(2) Upper Permian marine shales;

(3) Kimmeridgian (Upper Jurassic) marine shales.

The main potential is in the Upper Permian shales which are the most widespread and laterally the most consistent of the three units. The Carboniferous and Permian shales are oil-prone, while the Jurassic shales are gas-prone in the onshore areas of North-East Greenland but show a trend towards being oil-prone to the south (Table 1; Christiansen et al., in press; Stemmerik et al., in press).

\section{Conceptual plays}

Four conceptual play models have been considered in the preliminary evaluation of the hydrocarbon potential of the onshore areas:

(1) Upper Carboniferous play model with Upper Carboniferous shales as source rock and Upper Carboniferous fluviatile sandstones as reservoirs.

(2) Upper Permian play model where Upper Permian shales are source rocks and act as seal, and Upper Permian carbonates form the reservoirs.

(3) Upper Permian - Middle Jurassic play model where Upper Permian shales are source rocks, Middle Jurassic shelf sandstones form reservoirs and either Upper Jurassic or Lower Cretaceous shales are seal.

(4) Upper Permian - Lower Cretaceous play model where Upper Permian shales are source rocks, uppermost Jurassic - lowermost Cretaceous synrift conglom-

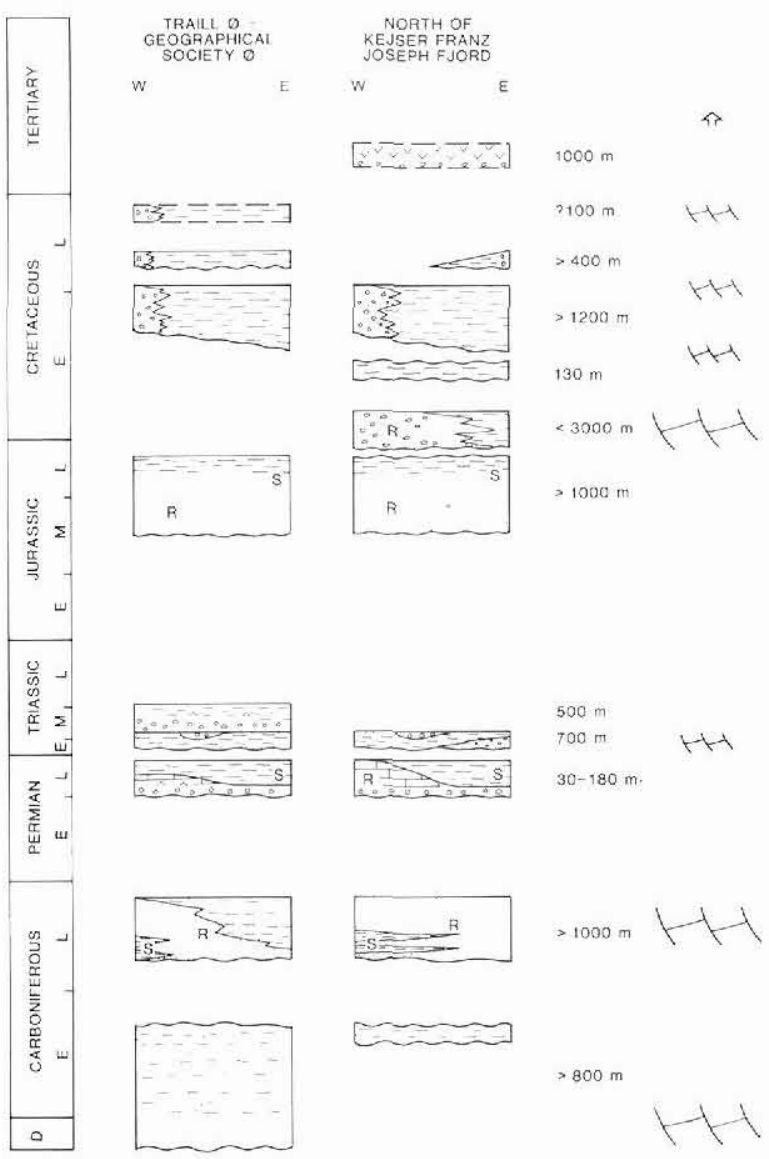

Conglomerate $\square$ sandstone $\square$ shate $\square$ Carbonate $\square$ Plateau basalts

Fig. 2. Stratigraphic scheme of the uppermost Devonian Tertiary succession. S marks position of potential source rocks and $\mathrm{R}$ indicates possible reservoirs. 
Table I. Characteristics of potential source rocks

\begin{tabular}{|c|c|c|c|c|}
\hline & $\begin{array}{c}\text { Thickness } \\
\text { (m) }\end{array}$ & $\begin{array}{c}\text { Initial } \\
\text { TOC }\end{array}$ & $\begin{array}{c}\text { Initial } \\
\mathrm{HI}\end{array}$ & $\begin{array}{c}\text { Generative } \\
\text { potential } \\
\text { (bbl } \times 10^{6} / \mathrm{km}^{2} \text { ) }\end{array}$ \\
\hline Upper Carbon. & $\begin{array}{c}\min .12 \\
(\max .50)\end{array}$ & 6 & 700 & $\begin{array}{l}8.4 \\
(35)\end{array}$ \\
\hline Upper Permian & 15 & 4 & 350 & 3.5 \\
\hline Upper Jurassic & $200(?)$ & 3 & 100 & $10(?)$ \\
\hline
\end{tabular}

erates and sandstones form reservoirs, and Lower Cretaceous shales act as seal.

The traps may be either structurally or stratigraphically controlled, or a combination of the two. Structural traps are the main targets in play models 1,3 and 4 whereas both structural and stratigraphic traps may be considered in play model 2. Structural analyses show examples of closures at top-Jurassic level on eastern Traill $\varnothing$ and similar structures may be present elsewhere in the area and also at different stratigraphic levels (Christiansen, 1990).

\section{Regional maturity}

The thermal maturity of surface samples of the organic-rich units has been studied using screening analyses including pyrolysis, vitrinite reflectance and Thermal Alteration Index, combined with more detailed analyses such as infrared spectroscopy, gas chromatography and gas chromatography/mass spectrometry.

All organic-rich shales are thermally immature sensu lato at the level of present day exposures, i.e. they have never been buried deeply enough to pass effectively into the oil-window. Where buried at adequate depths in the subsurface, however, they are likely to have generated significant amounts of hydrocarbons.

Anomalously high thermal maturities occur in the vicinity of large, mid-Tertiary syenite-granite intrusives and in areas with high concentrations of Tertiary dolerite dykes and sills. In these areas the shales are thermally postmature or even in the metamorphic stage (Stemmerik et al., in press).

\section{Hydrocarbon potential}

Without seismic and well data, the hydrocarbon potential of the area can only be evaluated within the frame of the four play models on the basis of the regional maturity pattern and inferred depositional and subsidence history.

Large areas can be rated as having insignificant hy-

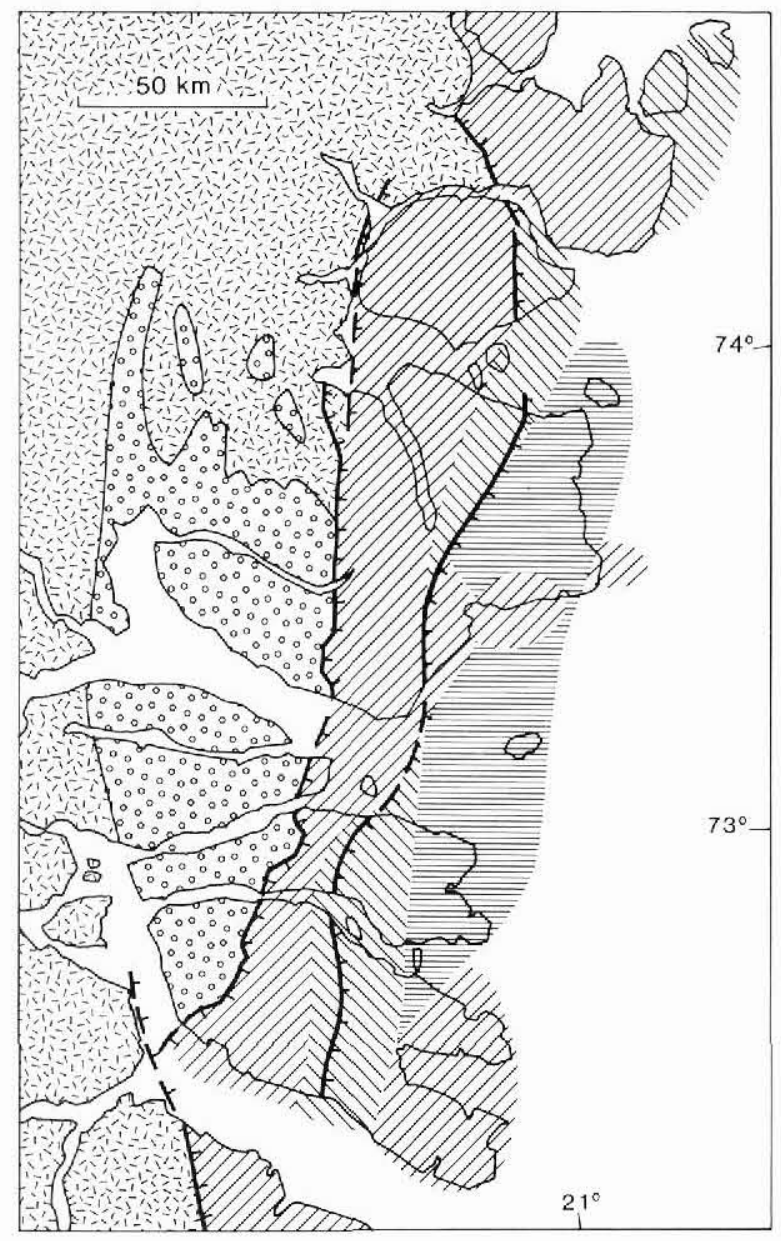

Carboniferous - Tertiary, fair exploration potential

Carboniferous - Tertiary, limited exploration potential

Carboniferous - Tertiary, no exploration potential

a Devonian

Pre-Devonian

Fig. 3. Map showing inferred exploration possibilities in the Carboniferous-Cretaceous basin with respect to the proposed play concepts.

drocarbon potential either because inferred source rocks are immature at the surface or because of postmaturity due to heating by Tertiary intrusives. About 6000 $\mathrm{km}^{2}$ of a total area of exposed Carboniferous-Cretaceous sediments of c. $40000 \mathrm{~km}^{2}$ are believed to be of further interest for hydrocarbon exploration (Fig. 3). In these areas, the organic-rich, Upper Palaeozoic shales have been down-faulted and may have reached the oilwindow during the Cretaceous when the shales were buried to a depth of approximately $3.5-4.5 \mathrm{~km}$. 
Since the Cretaceous the area has undergone episodes of Tertiary volcanism and subsequent uplift in the order of $c .1 \mathrm{~km}$. Both events may have degraded the hydrocarbon potential considerably, and the most promising prospects for future exploration are believed to be those with thick seals or prospects where the reservoir has been refilled by leaking and migration from deeper accumulations.

\section{References}

Christiansen, F. G. 1990: Mapping of Mesozoic sediments in Svinhufvuds Bjerge and Mols Bjerge, Traill $\emptyset$, North-East Greenland. Unpubl. intern. GGU rep., $18 \mathrm{pp}$.

Christiansen, F. G. \& Boserup, J. (compilers) 1990: Analytical key data for assessment of the petroleum potential of the northern part of the East Greenland basin. Unpubl. intern. GGU rep., 78 pp.

Christiansen, F. G., Olsen, H., Piasecki, S. \& Stemmerik, L. 1990a: Organic geochemistry of Upper Palaeozoic lacustrine shales in the East Greenland basin. Org. Geochem. 6, 287294.

Christiansen, F. G., Piasecki, S., Stemmerik, L. \& Telnæs, N. 1990b: Thermal maturation history of the Upper Permian Ravnefjeld Formation source rock in East Greenland. Unpubl. intern. GGU rep., 22 pp.

Christiansen, F. G., Piasecki, S., Stemmerik, L. \& Telnæs, N. 1990c: Depositional environment and organic geochemistry of the Upper Permian Ravnefjeld Formation source rock in East Greenland. Unpubl. intern. GGU rep., 39 pp.

Christiansen, F. G., Dam, G., Piasecki, S. \& Stemmerik, L. in press: A review of Upper Palacozoic and Mesozoic source rocks from onshore East Greenland. In Spencer, A. M. (ed.) Generation, accumulation and production of Europe's hydrocarbons. Proc. Europ. Ass. Petrol. Geol. 2.

Piasecki, S. \& Stemmerik, L. in press: Late Permian anoxia of central East Greenland. In Tyson, R. \& Pearson, T. (ed.) Modern and ancient shelf anoxia. Spec. Publ. geol. Soc. London 58.
Piasecki, S., Christiansen, F. G. \& Stemmerik, L. 1990: Depositional history of a Late Carboniferous organic-rich lacustrine shale from East Greenland. Bull. Can. Petrol. Geol. 38, 273-287.

Rasmussen, J. A., Piasecki, S., Stemmerik, L. \& Stouge, S. 1990: Late Permian conodonts from central East Greenland. Neues Jb. Geol. Paläont. Abh. 178, 309-324.

Stemmerik, L., Christiansen, F. G. \& Piasecki, S. 1991a: Lacustrine shales in East Greenland - an additional source rock in the North Atlantic? In Katz, B. J. (ed.) Lacustrine basin exploration: case studies and modern analogues. Mem. Am. Assoc. Petrol. Geol. 50, 277-286.

Stemmerik, L., Vigran, J. O. \& Piasecki, S. 1991b: Dating of Late Paleozoic rifting events in the North Atlantic: new biostratigraphic data from the uppermost Devonian and Carboniferous of East Greenland. Geology 19, 218-221.

Stemmerik, L., Christiansen, F. G., Piasecki, S., Jordt, B., Marcussen, C. \& Nøhr-Hansen, H. in press: Depositional history and petroleum geology of the Carboniferous to Cretaceous sediments in the northern part of East Greenland. In Vorren, T. O. et al. (ed.) Arctic geology and petroleum potential. Amsterdam: Elsevier for Norwegian Petroleum Society.

Surlyk, F. 1977: Stratigraphy, tectonics and palaeogeography of the Jurassic sediments of the areas north of Kong Oscars Fjord, East Greenland. Bull. Grønlands geol. Unders. 123, $56 \mathrm{pp}$

Surlyk, F. 1978: Submarine fan sedimentation along fault scarps on tilted fault blocks (Jurassic-Cretaceous boundary, East Greenland). Bull. Grønlands geol. Unders. 128, 108 pp.

Vigran, J. O. 1990a: Biostratigraphical zonation and dating of the Carboniferous strata in northern East Greenland. Unpubl. intern. GGU rep., $30 \mathrm{pp}$.

Vigran, J. O. 1990b: Sporomorph assemblages from the Carboniferous sequence in northern East Greenland. Unpubl. intern. GGU rep., $28 \mathrm{pp}$.

L. S., F. G. C. \& S. P., Geological Survey of Greenland, Copenhagen. 